\title{
PUTUSAN MAHKAMAH KONSTITUSI DALAM PEMBANGUNAN EKONOMI NASIONAL PADA PEMULIAAN TANAMAN DAN ALAT BERAT
}

\author{
(The Decision Of The Constitutional Court On The National Economy Development On The Plant \\ Breeding And Heavy Equipment)
}

\author{
Oly Viana Agustine \\ Pusat Penelitian dan Pengkajian Perkara Mahkamah Konstitusi \\ JI Medan merdeka Barat No. 6 Jakarta Pusat \\ Email: olyviana@mahkamahkonstitusi.go.id
}

Naskah diterima: 12 Februari 2018; revisi: 5 April 2018; disetujui: 17 April 2018

\begin{abstract}
Abstrak
Terdapat beberapa putusan MK yang memberikan sinergitas dengan pembangunan ekonomi nasional. Putusan MK Nomor 138/PUU-XIII/2015 dan putusan MK Nomor 3/PUU-XIII/2015 memberikan kesempatan bagi petani kecil perorangan dan pengusaha alat berat dalam menjalankan usahanya. Dengan diperbolehkannya para petani kecil perorangan dalam melakukan pemuliaan tanaman dan dihapuskannya ketentuan alat berat yang tidak lagi digolongkan sebagai kendaraan bermotor bagi pelaku usaha di bidang alat berat, diharapkan dapat mendukung pembangunan ekonomi nasional dari sektor industri kecil di bidang pemuliaan tanaman dan alat berat. Berangkat dari kedua putusan tersebut, dalam penelitian ini penulis ingin melihat bagaimana peran putusan MK dalam membangun ekonomi nasional pada pemuliaan tanaman dan alat berat. Metode penelitian yang digunakan adalah yuridis normatif dengan studi kasus putusan MK. Kesimpulan yang didapat dalam penelitian ini bahwa melalui putusan MK Nomor 138/PUU-XIII/2015 dan putusan MK Nomor 3/PUUXIII/2015 telah mendukung pembangunan ekonomi nasional dalam bidang pemuliaan tanaman bagi petani perorangan dan industri alat berat. Oleh sebab itu perlu menindaklanjuti putusan MK dan segera diimplementasikan oleh semua adresat dalam putusan MK tersebut.
\end{abstract}

Kata Kunci: ekonomi nasional, pembangunan, putusan Mahkamah Konstitusi

\begin{abstract}
There are some Constitusional Court decision that is synergic with the national economy development. The Constitutional Court Decision Number 138/PUU-XIII/2015 and 3/PUU-XIII/2015 provide opportunities for individuals farmers and entrepreneurs of heavy equipment in running their business. The permission for individual smallholders to do plant breeding and the elimination of heavy equipment provisions that are no longer classified as motor vehicles for business actors in the field of heavy equipment, are expected to support the national economic development of the small industrial sector in the field of plant breeding and heavy equipment. Departing from these two decisions, this study aims to see how the role of the Constitutional Court decision in building the national economy on plant breeding and heavy equipment. The research method used is normative juridical with case study of Constitutional Court decision. The conclusion shows that through the decision of the Constitutional Court Number 138/PUU-XIII/2015 and 3/PUU-XIII/2015 has supported the national economic development in the field of plant breeding for individual farmers and heavy equipment industry. These decisions need to be followed up and implemented immediately by all adresat in the Constitutional Court decision.
\end{abstract}

Keywords: national economy, development, decision of the Constitutional Court 


\section{A. Pendahuluan}

Salah satu tujuan adanya hukum adalah sebagai alat perekayasa sosial. Hukum tercermin baik dalam peraturan maupun putusan hakim, mengandung makna akan adanya ketertiban hukum dan pedoman tingkah laku manusia. Salah satu kewenangan Mahkamah Konstitusi (MK) adalah melakukan pengujian undangundang terhadap Undang-Undang Dasar Negara Republik Indonesia tahun 1945 (selanjutnya disebut UUD NRI 1945), yang artinya apabila ada undang-undang yang bertentangan dengan UUD NRI 1945 maka ketentuan norma dalam undang-undang tersebut baik secara materiil atau formil dapat dibatalkan baik sebagian maupun seluruhnya. Putusan MK Nomor 138/ PUU-XIII/2015 dan putusan MK Nomor 3/PUUXIII/2015 menyatakan bahwa dalam pengujian kedua undang-undang tersebut, terdapat pertentangan antara norma yang diatur dalam Undang-Undang Nomor 39 Tahun 2014 tentang Perkebunan dan Undang-Undang Nomor 22 Tahun 2009 tentang Lalu Lintas dan Angkutan Jalan (UU LLAJ) dengan Undang-Undang Dasar 1945. Pada kedua pengujian undang-undang tersebut MK mengabulkan permohonan para Pemohon dan menyatakan ketentuan dalam undang-undang a quo bertentangan dan tidak memiliki kekuatan hukum mengikat. Pada putusan 138/PUU-XIII/2015 MK memberikan ruang bagi petani kecil perorangan dalam melakukan pemuliaan tanaman, dimana sebelum ada putusan a quo petani kecil harus memperoleh izin dalam melakukan pemuliaan tanaman,sedangkan dalam putusan 3/PUUXIII/2015, MK menghapus ketentuan dimana alat berat tidak lagi digolongkan sebagai kendaraan bermotor sebagaimana diatur sebelumnya pada UU LLAJ.
Dengan adanya dua putusan a quo telah memberikan kepastian hukum yang diharapkan mampu mendorong upaya pembangunan ekonomi nasional melalui petani kecil perorangan untuk melakukan pemuliaan tanaman dan pengusaha alat berat dalam usaha konstruksi karena tidak perlu mengikuti uji tipe dan uji berkala terhadap alat beratnya seperti halnya kendaraan bermotor. Putusan MK berperan sebagai hukum yang sangat strategis dalam pembangunan ekonomi nasional dengan memberikan bimbingan, pedoman ramburambu serta alat untuk mencapai tujuan pembangunan ekonomi nasional.

Namun tidak dipungkiri, bahwa putusan MK yang bersifat final dan mengikat terkadang menemukan hambatan dalam hal implementasi. Hal ini dapat dilihat bagaimana addresat putusan dalam hal ini pemerintah dan DPR menormakan ketentuan yang telah diputus MK. Jika demikian, tentu akan merugikan upaya pembangunan ekonomi nasional karena tidak adanya kepastian hukum bagi pelaku usaha. Oleh karena itu, perlu adanya kesadaran dan kemauan bagi addresat putusan untuk melaksanakan putusan MK. Dalam perspektif negara hukum yang demokratis, diimplementasikannya putusan MK merupakan kewajiban hukum. Apalagi jika dikaitkan dengan pemenuhan hak konstitusional warga negara yang dijamin oleh UUD NRI 1945. Berdasarkan penjelasan tersebut, menarik untuk melihat bagaimana Peran putusan Mahkamah Konstitusi dalam membangun ekonomi nasional pada bidang pemuliaan tanaman dan alat berat? dan pada pembahasan selanjutnya, akan dipaparkan mengenai subbab-subbab yang mendukung untuk menjawab permasalahan yang telah dipaparkan. Antara lain: Putusan Mahkamah Konstitusi Nomor 138/PUU-XIII/2015, implikasi 
Putusan Mahkamah Konstitusi Nomor 138/ PUU-XIII2015 terhadap pembangunan ekonomi nasional oleh petani kecil di bidang pemuliaan tanaman, Putusan Mahkamah Konstitusi Nomor 3/PUU-XIII/2015, implikasi putusan MK Nomor 3/PUU-XIII/2015 dalam pembangunan ekonomi nasional di bidang alat berat, dan prinsip kepastian hukum dalam putusan MK sebagai upaya mendorong pembangunan ekonomi nasional serta hambatan implementasi putusan MK dalam mewujudkan pembangunan ekonomi nasional.

\section{B. Metode Penelitian}

Metode penelitian yang digunakan dalam penelitian ini adalah yuridis normatif dengan menggunakan case study. Kasus-kasus yang dipelajari dan dianalisis adalah beberapa putusan MK yang terkait dengan putusan yang memiliki dampak terhadap pembangunan ekonomi terutama pada bidang pemuliaan tanaman dan alat berat, yaitu putusan MK Nomor 138/PUU-XIII/2015 dan Putusan MK Nomor 3/PUU-XIII/2015 yang didapatkan langsung melalui laman MK. Selain terhadap putusan MK, buku, jurnal dan literatur lain yang menunjang dan berhubungan sebagai bahan penelaahan hukum terhadap kaidah yang dianggap sesuai dengan penelitian hukum tertulis. Penelitian normatif dilakukan terhadap hal-hal yang bersifat teoritis asas-asas hukum, dasar hukum dan konsep-konsep hukum. ${ }^{1}$ Dalam penelitian ini, penulis mengumpulkan bahan hukum berupa putusan MK dan menganalisisnya dengan menggunakan teori tentang interrelasi hukum dan ekonomi, konstitusonalisme dan konsepsi negara hukum untuk mendapatkan jawaban dari permasalahan.

\section{Pembahasan}

1. Peran Putusan MK dalam Pembangunan Ekonomi Nasional: Studi Interrelasi antara Hukum dan Ekonomi

UUD NRI 1945 dan Pancasila adalah pondasi dalam pembangunan ekonomi nasional. Pembangunan ekonomi merupakan salah satu upaya untuk mewujudkan kesejahteraan rakyat yang adil dan makmur berdasarkan Pancasila dan UUD NRI 1945. Pasal 33 ayat (1), (2), (3) dan

(4) UUD NRI 1945 menyatakan bahwa:

(1) Perekonomian disusun sebagai usaha bersama berdasar atas asas kekeluargaan.

(2) Cabang-cabang produksi yang penting bagi negara dan yang menguasai hajat hidup orang banyak dikuasai oleh negara.

(3) Bumi dan air dan kekayaan alam yang terkandung di dalamnya dikuasai oleh negara dan dipergunakan untuk sebesarbesar kemakmuran rakyat.

(4) Perekonomian nasional diselenggarakan berdasarkan atas demokrasi ekonomi dengan prinsip kebersamaan, efisien, berkeadilan, berkelanjutan, berwawasan lingkungan, kemandirian, serta dengan menjaga keseimbangan kemajuan dan kesatuan ekonomi nasional.

Sebelum adanya penegasan dengan ditambahkannya perkataan "perekonomian nasional", Pasal 33 ayat (1), (2), (3), dan Pasal 34 ayat (1) sudah ada dalam naskah UUD NRI 1945 sebagaimana yang disahkan pada tanggal 18

Abdulkadir Muhammad, Hukum dan Penelitian Hukum. (Bandung: Citra Aditya Bakti, 2004), hlm. 57. 
Agustus 1945. Karena kebijakan konstitusional perekonomian nasional menurut UUD NRI 1945 pasca perubahan haruslah tetap dibaca dan dipahami dalam perspektif kesejahteraan sosial yang menjadi judul asli Bab XIV NRI UUD 1945. Tambahan frasa "perekonomian nasional" dan bahkan penyebutannya lebih dulu daripada kesejahteraan sosial adalah penegasan bahwa UUD NRI 1945 merupakan konstitusi yang di dalamnya diatur bukan saja mengenai aspekaspek politik kenegaraan tetapi juga mengenai haluan-haluan dasar mengenai kebijakan perekonomian negara. ${ }^{2}$

Bangsa Indonesia memberikan makna pembangunan nasional sebagai rangkaian upaya pembangunan yang berkesinambungan, yang meliputi kehidupan masyarakat, bangsa dan negara untuk melaksanakan tugas mewujudkan tujuan nasional yang tersusun dalam pembukaan UUD NRI 1945. Dengan demikian tujuan pembangunan nasional adalah untuk mewujudkan suatu masyarakat yang adil dan makmur yang merata spiritual dan material berdasarkan negara yang merdeka, bersatu, berdaulat, dan berkedaulatan rakyat dalam suasana perikehidupan bangsa yang aman, tenteram, tertib, dan dinamis dalam lingkungan pergaulan dunia yang merdeka, bersahabat tertib, dan damai. ${ }^{3}$

Hukum dalam keberadaannya di masyarakat mempunyai peranan dan pengaruh terhadap kegiatan ekonomi sesuai dengan fungsi hukum itu sendiri. Hukum dalam fungsinya berisi petunjuk tingkah laku manusia, alat untuk menyelesaikan konflik dan alat untuk rekayasa sosial ekonomi. ${ }^{4}$ Pembangunan ekonomi tidak dapat dipisahkan dari pembangunan hukum, karena antara ekonomi dan hukum itu merupakan dua hal yang saling mempengaruhi satu sama lain. Hukum sebagai ketentuan yang sifatnya normatif mempunyai peran dan fungsi yang sangat penting dalam perekonomian.

Menurut Satjipto Rahardjo, hukum berfungsi sebagai perlindungan bagi kepentingan manusia, dan karenanya hukum harus dilaksanakan. ${ }^{5}$ Selanjutnya Ronny Hanitidjo dengan menyisir pendapat Talcott Parsons menyatakan bahwa, fungsi utama hukum adalah melakukan integrasi, yaitu mengurangi konflik-konflik dan melancarkan proses interaksi pergaulan sosial. ${ }^{6}$ Fungsi internal hukum itu sendiri sudah sangat berpengaruh dalam kehidupan manusia, utamanya dalam kehidupan ekonomi. Thomas Aquinas menegaskan dalam konteks ini, bahwa fungsi hukum mengusahakan kesejahteraan seluruh umat manusia. Fungsi disini adalah sebagai kerangka yang berwujud peraturan yang membimbing, memberikan pedoman sanksi dan alat untuk kehidupan sosial. Obyeknya adalah segala segi kehidupan manusia dalam kehidupan ekonominya. $^{7}$

Jimly Asshiddiqie, Gagasan Kedaulatan Rakyat dalam Konstitusi dan Pelaksanannya di Indonesia, Disertasi Doktor dalam Ilmu Hukum Fakultas Hukum Universitas Indonesia, Jakarta 1991. Disertasi ini diterbitkan menjadi buku oleh Ichtiar Baru-Van Hoeve, Jakarta, 1994. Baca juga Jimly Asshiddiqie, Konstitusi Ekonomi (Jakarta: Penerbit Kompas, 2010), hlm. 96-97.

3 Neni Sri Imaniyati, Hukum Ekonomi dan Ekonomi Islam, (Bandung: Mandar Maju, 2002), hlm. 8.

4 Gunarto Suhardi, Peranan Hukum Dalam Pembangunan Ekonomi, (Yogyakarta: Universitas Atmajaya, 2002), hlm. 27.

5 Neni Sri Imaniyati, Hukum Bisnis Telaah Tentang Pelaku dan Kegiatan Ekonomi, (Yogyakarta: Graha Ilmu, 2009), hlm. 40.

6 Ronny Hanitidjo Soemitro, Studi Hukum Dalam Masyarakat, (Bandung: Alumni, 1982), hlm. 10.

7 Gunarto Suhardi, Op.Cit., hlm. 27. 
JD Ny Hart mengemukakan adanya enam konsep hukum yang mempunyai pengaruh bagi pengembangan kehidupan ekonomi, yaitu: ${ }^{8}$

1. Prediktabilitas

Hukum harus mempunyai kemampuan untuk memberikan gambaran pasti di masa depan mengenai keadaan atau hubunganhubungan yang dilakukan pada masa sekarang.

2. Penyeimbangan

Sistem hukum harus dapat menjadi kekuatan yang memberikan keseimbangan di antara nilai-nilai yang bertentangan di dalam masyarakat. Sistem hukum memberikan kesadaran akan keseimbangan dalam usahausaha negara melakukan pembangunan ekonomi.

3. Definisi dan kejernihan tentang status Disamping fungsi hukum yang memberikan prediktabilitas dapat ditambahkan bahwa fungsi hukum juga memberikan ketegasan mengenai status orang-orang dan barangbarang di masyarakat.

4. Akomodasi

Perubahan yang cepat sekali pada hakikatnya akan menyebabkan hilangnya keseimbangan yang lama, baik dalam hubungan antara individu maupun kelompok di dalam masyarakat. Keadaan ini dengan sendirinya menghendaki dipulihkannya keseimbangan tersebut melalui satu dan lain jalan. Disini sistem hukum yang mengatur hubungan antara individu baik secara material maupun formal memberikan kesempatan kepada keseimbangan yang terganggu itu untuk menyesuaikan diri kepada lingkungan yang baru sebagai akibat perubahan tersebut.
Pemulihan kembali ini dimungkinkan oleh karena di dalam kegoncangan ini sistem hukum memberikan pegangan kepastian melalui perumusan-perumusan yang jelas dan definitif membuka kesempatan bagi dipulihkannya keadilan melalui prosedur yang tertib dan sebagainya.

5. Kemampuan prosedur

Pembinaan di bidang hukum acara memungkinkan hukum material itu dapat merealisasikan dirinya dengan baik, ke dalam pengertian hukum acara ini termasuk tidak hanya ketentuan-ketentuan hukum perundang-undangan melainkan juga semua prosedur penyelesaian yang disetujui oleh para pihak yang bersengketa, misalnya bentuk-bentuk: arbitrasi, konsialiasi, dan sebagainya, semua lembaga tersebut hendaknya dapat bekerja dengan efisien apabila diharapkan. Bahwa kehidupan ekonomi itu ingin mencapai tingkatannya yang maksimum.

6. Kodifikasi daripada tujuan-tujuan

Perundang-undangan dapat dilihat sebagai suatu kodifikasi tujuan serta maksud sebagaimana dikehendaki oleh negara. Di bidang ekonomi misalnya, kita akan dapat menjumpai tujuan-tujuan itu seperti dirumuskan di dalam beberapa perundangundangan yang secara langsung atau tidak langsung mempunyai pengaruh terhadap bidang perekonomian.

Salah satu teori yang membahas peranan negara yang dikuasakan oleh hukum untuk mendorong dinamika kegiatan pembangunan ekonomi yaitu teori yang dikemukakan oleh

8 Sulistyo, Adi dan Muhammad Rustamaji, Hukum Ekonomi Sebagai Panglima, (Sidoarjo: Masmedia Buana Pustaka, 2009), hlm. 20-21. 
F. Friedmann. Geelhoed dan Zilstra $^{9}$ yang dikombinasikan oleh Suhardi Gunarto dalam tiga tipologi atau kategori peranan negara atas nama hukum ${ }^{10}$ yakni:

a. Negara bertindak sebagai regulator (sturende) dan juri (wasit) dengan memakai instrumen hukum administrasi yang umum dan indivudual khusus;

b. Negara bertindak sebagai penyedia atau provider (the presterende) dari berbagai keperluan para warga negaranya yang menurut Zijlstra dapat berupa tindakan yang masuk dalam tipologi pemberian tunjangan sosial dan tindakan lainnya yang mengarah pada sociale rechtstaat. Geelhoed menyebut fungsi ini sebagai de presterende yang masuk dalam kategori penyelenggaraan Negara. Dalam hal ini Friedmann juga menyebut dalam bahasanya fungsi provider ini merupakan perwujudan dan tugas pokok negara dalam sistem social welfare state seperti yang terjadi pada kebanyakan negara-negara barat melalui berbagai peraturan yang disebutkan dalam kelompok social security act, health insurance act dan lain-lain.

c. Peranan negara sebagai interpreneur atau pengusaha. Ini dilakukan oleh negara dengan membentukbadan-badan usaha miliknegara (BUMN) yang disamping melaksanakan fungsi sebagai agent of development juga harus mampu berusaha untuk membiayai usahanya secara mandiri (tidak masuk

dalam anggaran belanja pemerintah) dan memberikan manfaat bagi negara dengan membayar pajak pendapatan sebagaimana umumnya badan usaha lainnya.

Pembangunan ekonomi, bagaimanapun juga memerlukan dukungan kelembagaan dan sistem norma yang mengatur dan mengarahkan secara efektif dan efisien agar tujuan kesejahteraan yang adil dan merata dapat dicapai dengan sebaik-baiknya. Karena itu, sistem ekonomi dan kebijakan pembangunan ekonomi harus tunduk kepada kesepakatan hukum tertinggi, yaitu Pancasila dan UUD NRI 1945 sebagai dasar desain hukum konstitusi (constitutional law) dan etika konstitusi (constitutional ethics) yang harus menjadi landasan sistem ekonomi dan kebijakan pembangunan ekonomi nasional. ${ }^{11}$

Kehadiran MK dalam sistem ketatanegaraan Indonesia merupakan tuntutan atau konsekuensi teoritis dari perubahan yang dilakukan terhadap UUD NRI 1945. Pembentukan MK yang diadopsi dari perubahan ketiga UUD NRI 1945 adalah bagian dari upaya untuk menegakkan prinsip constitutionalism yang merupakan syarat pertama negara hukum yang demokratis. ${ }^{12}$ Salah satu fungsi utama konstitusi adalah untuk memberikan perlindungan terhadap individu dan hak-hak dasar dari individu-individu. Ketika hak-hak dasar telah dijamin oleh konstitusi maka ia menjadi hak-hak konstitusional. Doktrin konstitusionalisme menekankan bahwa perlindungan terhadap hak-hak dasar 
atau hak-hak konstitusional itu hanya mungkin diwujudkan apabila kekuasaan negara dibatasi oleh dan melalui konstitusi. ${ }^{13}$

Dalam penegakan hukum, hakim mempunyai peran sentral, baik hakim Pengadilan Negeri, Pengadilan Tinggi, Mahkamah Agung, maupun hakim Mahkamah Konstitusi. Dalam penyelenggaraan peradilan, hakim melakukan penerapan hukum yang abstrak sifatnya pada peristiwa yang konkrit. Karena beranekaragamnya kegiatan kehidupan masyarakat dan cepatnya perkembangan dan perubahannya, maka tidak mungkin tercakup dalam satu peraturan perundang-undangan dengan tuntas dan jelas. Oleh karenanya sudah wajar kalau tidak ada peraturan perundangundangan yang dapat mencakup keseluruhan kegiatan kehidupan manusia, sehingga tidak ada peraturan perundang-undangan yang lengkap dan jelas. Karena hukumnya tidak lengkap dan tidak jelas, maka harus dicari dan diketemukan. Terlebih lagi mengingat ada kemungkinan suatu perkara yang dihadapkan pada hakim belum ada peraturan hukumnya, atau peraturan hukumnya ada tetapi tidak jelas, seharusnya hakim dapat melakukan penemuan hukum, bahkan sekaligus juga pembentukan hukum. ${ }^{14}$

Peran putusan hakim baik di negara-negara penganut tradisi common law maupun civil law, cukup signifikan dalam menentukan pembangunan ekonomi di masing-masing negara. Putusan hakim adalah hukum yang hidup di masyarakat yang menjawab pertanyaan dan problematika kontemporer. Eksistensi hakim sebagai salah satu unsur dari hukum, banyak menentukan corak keberadaan suatu sistem hukum sebagaimana didasarkan pada paham yang berkembang dalam masyarakat Amerika (realisme hukum Amerika), bahwa putusan hakim adalah hukum yang sebenarnya dalam perkara konkret. Undang-undang, kebiasaan, dan seterusnya hanya pedoman dan bahan inspirasi bagi hakim untuk membentuk hukumnya sendiri. ${ }^{15}$

Putusan MK dalam pengujian undangundang adalah menjawab permasalahan kontemporer. MK melalui putusannnya dapat memiliki peran dalam pembangunan ekonomi nasional dengan menghadirkan keadilan, kemanfaatan, dan kepastian hukum. Tidak dipungkiri bahwa keadilan, kemanfaatan, dan kepastian hukum merupakan faktor penting untuk mendorong pembangunan ekonomi nasional. Dengan adanya keadilan dan kemanfaatan dapat menciptakan sinergitas antara pengusaha dan pekerja, sedangkan dengan kepastian hukum merupakan jaminan dalam berusaha dan berinvestasi.

Ketiga prinsip tersebut telah dihadirkan MK melalui putusan MK Nomor 138/PUUXIII/2015 dan Putusan MK Nomor 3/PUU$\mathrm{XIII/2015}$. Dari kedua putusan a quo, terlihat bagaimana MK menjalankan fungsinya sebagai penjaga konstitusi yang menghadirkan peran negara dalam pembangunan ekonomi dengan melibatkan petani kecil perorangan di bidang usaha pemuliaan tanaman dan bagi pelaku usaha konstruksi dengan membebaskan kewajiban uji tipe dan uji berkala terhadap alat berat. MK senantiasa menjaga dan menciptakan tafsir

\footnotetext{
Ibid., hlm. 102-103.

Jimly Asshiddiqie, Op.Cit., hlm. 285.

5 R.M. Panggabean, Budaya Hukum Hakim Dibawah Pemerintahan Demokrasi dan Otoriter (Studi Tentang PutusanPutusan Mahkamah Agung RI 1950-1965), (Jakarta: Pusat Studi Hukum dan Ekonomi Fakultas Hukum Universitas Indonesia, 2008), hlm. 56-57.
} 
konstitusi sebagai pengaman agar pelaksanaan pembangunan ekonomi tidak mengorbankan hak dan kepentingan warga negara. Hal ini sejalan dengan bunyi ketentuan dalam Pasal $28 \mathrm{H}$ ayat (2) UUD NRI 1945 menyatakan setiap orang berhak mendapat kemudahan dan perlakuan khusus untuk memperoleh kesempatan dan manfaat yang sama guna mencapai persamaan dan keadilan, dan Pasal 28I ayat (2) UUD NRI 1945 menyatakan setiap orang bebas dari perlakuan yang bersifat diskriminatif atas dasar apapun dan berhak mendapatkan perlindungan terhadap perlakuan yang bersifat diskriminatif itu.

Makna yang tekandung pada Pasal $28 \mathrm{H}$ ayat (2) UUD NRI 1945 yakni bahwa semua orang sama di hadapan hukum dan berhak atas perlindungan hukum yang sama tanpa diskriminasi. Semua berhak atas perlindungan yang sama terhadap setiap bentuk apapun. Sedangkan makna pada Pasal 281 ayat (2) UUD NRI 1945 mengandung makna bahwa setiap orang bebas atas perlakuan seseorang dan mendapat perlindungan dari pemerintah agar tidak terjadi lagi konflik atau perselisihan yang berkelanjutan dan berkepanjangan ataupun permasalahan yang sewaktu-waktu tidak diselesaikan atau tidak terpecahkan sama sekali.

\section{Putusan Mahkamah Konstitusi Nomor 138/PUU-XIII/2015}

Pada perkara nomor 138/PUU-XIII/2015 yang dimohonkan oleh berbagai organisasi non pemerintah (badan hukum privat) yakni: Serikat Petani Kelapa Sawit (SPKS), Perkumpulan Sawit Watch, Aliansi Petani Indonesia (API), Serikat Petani Indonesia (SPI), Yayaysan Bina Desa Sadawijaya (Bina Desa), dan Farmer Initiatives for Ecological Livelihood and Democracy (Field) terdapat 12 norma yang dimohonkan oleh para Pemohon, yakni Pasal 12, Pasal 13, Pasal 27 ayat (3), Pasal 29, Pasal 30 ayat (1), Pasal 42, Pasal 55, Pasal 57, dan Pasal 58 ayat (1), Pasal 58 ayat (2), dan Pasal 107 serta Pasal 114 ayat (3) UU Perkebunan. Dari 12 norma yang dimohonkan pengujian, terdapat beberapa isu yang menarik yakni adanya pembatasan terhadap petani kecil dalam usaha pemuliaan tanaman dan pembatasan terhadap petani kecil dalam penelitian untuk menemukan atau melakukan penukaran benih-benih baru. Dalam keterangannya Pemerintah dalam persidangan mengungkapkan bahwa pengujian atau penilaian varietas benih harus dilakukan sebagai upaya menjamin mutu benih yang akan diedarkan. Oleh karena itu, pada saat produksi benih dilakukan serangkaian sertifikasi agar dapat dipertahankan mutu benih dan kemurnian varietas.

Sebelumnya pada persidangan terungkap bahwa para petani mengaku telah berhasil mengembangkan varietas benih unggul sesuai dengan kondisi wilyahnya, namun varietas tersebut dianggap ilegal oleh Dinas Pertanian dengan alasan benih yang ditemukan belum memiliki sertifikasi sehingga dilarang untuk digunakan. Hal ini merupakan konsekuensi diaturnya ketentuan pada Pasal 27 ayat (3) UU Perkebunan yang menyatakan bahwa, "Kegiatan pencarian dan pengumpulan sumber daya genetik sebagaimana dimaksud pada ayat (2) dapat dilakukan oleh orang perseorangan atau badan hukum berdasarkan izin Menteri".

Padahal, dalam UU a quo menyebutkan bahwa penyelenggaraan perkebunan diarahkan untuk mencapai tujuan: (a) meningkatkan kesejahteraan dan kemakmuran rakyat; (b) meningkatkan sumber devisa negara; (c) menyediakan lapangan kerja dan kesempatan usaha; (d) meningkatkan produksi, produktivitas, 
kualitas, nilai tambah, daya saing, dan pangsa pasar; (e) meningkatkan dan memenuhi kebutuhan konsumsi serta bahan baku industri dalam negeri; (f) memberikan perlindungan kepada Pelaku Usaha Perkebunan dan masyarakat; (g) mengelola dan mengembangkan sumber daya Perkebunan secara optimal, bertanggung jawab, dan lestari; dan (h) meningkatkan pemanfaatan jasa Perkebunan. Oleh karena itu, dalam pertimbangannya, MK menyatakan ${ }^{16}$ :

c) Bahwa substansi norma yang terkandung dalam Pasal 27 ayat (3) UU Perkebunan ternyata sama dengan substansi norma yang terkandung dalam Pasal 9 ayat (3) Undang-Undang Nomor 12 Tahun 1992 tentang Sistem Budidaya Tanaman (selanjutnya disebut UU 12/1992) yang berbunyi, "Kegiatan pencarian dan pengumpulan plasma nutfah sebagaimana dimaksud dalam ayat (2), dapat dilakukan oleh perorangan atau badan hukum berdasarkan izin";

d) Bahwa terhadap Pasal 9 ayat (3) UU 12/1992 tersebut pada huruf $b$ di atas oleh Mahkamah telah dinyatakan inkonstitusional bersyarat berdasarkan Putusan Nomor 99/PUU-X/2012, bertanggal 18 Juli 2013. Dalam putusan dimaksud, Mahkamah telah pada intinya mengakui hak perorangan petani kecil untuk pemuliaan tanaman tanpa harus meminta izin. Oleh karena itu, pertimbangan hukum Mahkamah dalam putusan dimaksud berlaku pula terhadap Pasal 27 ayat (3) UU Perkebunan dalam permohonan a quo sehingga Pasal 27 ayat (3) UU Perkebunan bertentangan dengan UUD 1945 sepanjang kata "orang perseorangan" dalam ketentuan dimaksud tidak dimaknai tidak termasuk orang perseorangan petani kecil.
Sejalan dengan ketentuan a quo, menjawab ketentuan dalam Pasal 29 UU Perkebunan yang berbunyi: "Pemerintah Pusat, Pemerintah Daerah sesuai dengan kewenangannya, atau Pelaku Usaha Perkebunan dapat melakukan pemuliaan tanaman untuk menemukan varietas unggul," MK berpendapat bahwa:

b) Bahwa pengertian pemuliaan tanaman adalah rangkaian kegiatan untuk mempertahankan kemurnian jenis dan/ atau varietas yang sudah ada atau menghasilkan jenis dan/atau varietas baru yang lebih baik (vide Pasal 1 angka $3 \cup \cup$ 12/1992);

c) Bahwa pemuliaan tanaman berkait langsung dengan kegiatan pencarian dan pengumpulan sumber daya genetik, sebagaimana diatur dalam Pasal 27 UU Perkebunan, sementara dalam pertimbangan pada angka 3 di atas "perseorangan petani kecil" telah dinyatakan diakui keabsahannya untuk melakukan pencarian dan pengumpulan sumber daya genetik maka dengan sendirinya pengakuan dan keabsahan demikian juga berlaku terhadap kegiatan pemuliaan tanaman untuk menemukan varietas unggul sebagaimana dimaksud dalam Pasal 29 UU Perkebunan;

d) Bahwa pertimbangan pada huruf b) di atas sejalan dengan Putusan Mahkamah Nomor 99/PUU-X/2012, bertanggal 18 Juli 2013, yang telah pula dijadikan bagian dari pertimbangan pada angka 3 di atas;

Bahwa dengan demikian, dalil para Pemohon sepanjang berkenaan dengan inkonstitusionalitas Pasal 29 UU Perkebunan adalah beralasan untuk sebagian sehingga Pasal 29 UU Perkebunan harus dinyatakan bertentangan dengan UUD 1945 sepanjang tidak dimaknai "termasuk perorangan petani kecil". 


\section{Implikasi Putusan MKNomor 138/PUU- XIII/2015 terhadap Pembangunan Ekonomi Nasional oleh Petani Kecil di Bidang Pemuliaan Tanaman}

Dengan dikabulkannya sebagian uji materi sejumlah pasal dalam Undang-Undang perkebunan yang dimohonkan oleh sejumlah pertani, MK melalui putusan Nomor 138/PUUXIII/2015 menegaskan bahwa petani kecil dapat mencari dan menemukan varietas pemuliaan tanaman unggul tanpa izin Menteri Pertanian. Hal ini sejalan dengan Putusan MK sebelumnya Nomor 99/PUU-X/2012, yang menyatakan bahwa petani kecil memiliki potensi yang besar, sehingga Pemerintah wajib melindungi. Apabila ada usaha-usaha petani yang tujuannya untuk mendapatkan varietas atau benih yang baik, Pemerintah wajib untuk memberikan bimbingan sejak dini supaya upaya tersebut dapat berhasil dengan baik dan tidak hanya terlibat dalam proses akhir yaitu pemberian sertifikasi saja.

Dalam amar putusannya, MK menyatakan frasa "orang perseorangan" dalam Pasal 27 ayat (3) dan Pasal 29 UU Perkebunan, inkonstitusional bersyarat sepanjang dimaknai orang perseorangan termasuk petani kecil. Di dalam pertimbangannya MK menyebut norma dalam Pasal 27 ayat (3) UU Perkebunan sama dengan substansi norma dalam Pasal 9 ayat (3) UU Nomor 12 Tahun 1992 tentang Sistem Budidaya Tanaman (UU Sistem Budidaya Tanaman) yang telah dinyatakan inkonstitusional bersyarat berdasarkan Putusan Nomor 99/PUU-X/2012. Dalam putusan Nomor 99/PUU-X/2012 tersebut, MK meyatakan inkonstitusional bersyarat Pasal 29 UU Perkebunan yang berbunyi, "Pemerintah Pusat, Pemerintah Daerah, atau Pelaku Usaha Perkebunan dapat melakukan pemuliaan tanaman untuk menemukan varietas unggul" sepanjang dimaknai "termasuk perorangan petani kecil". MK juga menyatakan inkonstitusional bersyarat Pasal 30 ayat (1) UU Perkebunan yang berbunyi, "Varietas hasil pemuliaan atau introduksi dari luar negeri sebelum diedarkan terlebih dahulu harus dilepas oleh Pemerintah Pusat atau diluncurkan oleh Pemilih Varietas" dimaknai tidak perlu bagi varietas hasil pemuliaan yang dilakukan oleh perorangan petani kecil dalam negeri untuk komunitas sendiri.

Putusan MK Nomor 138/PUU-XIII/2015 menjadi bersejarah dalam perkebunan di Indonesia yang diharapkan menjadi pintu pembuka reforma agraria di kawasan perkebunan, khususnya dalam persoalan tanah, perbenihan dan kriminalisasi para petani. Dengan putusan ini memberikan implikasi bagi petani kecil dimana dalam mencari dan mengumpulkan sumberdaya genetik, melakukan pemuliaan tanaman untuk menemukan varietas unggul dan mengedarkan varietas hasil pemuliaan ke komunitasnya tidak memerlukan izin dari Pemerintah.

\section{Putusan MK Nomor 3/PUU-XIII/2015}

Pada pengujian UU LLAJ, perkara nomor 3/PUU-XIII/2015 yang dimohonkan oleh para pemohon yakni PT Tunas Jaya Pratama, PT Multi Prima Universal dan PT Marga Maju Japan terdapat putusan MK yang memberikan langkah bagi pengusaha yang bergerak di bidang alat berat.

Awalnya para Pemohon yang merupakan badan hukum privat pemilik dan/atau pengelola alat berat merasa dirugikan dan/atau berpotensi dirugikan hak-hak konstitutionalnya dengan diberlakukannya penjelasan Pasal 47 ayat (2) huruf e bagian c UU LLAJ yang menempatkan alat berat sebagai kendaraan bermotor, sehingga para Pemohon merasa dirugikan haknya yaitu 
hak atas pengakuan, jaminan, perlindungan, dan kepastian hukum yang adil serta perlakuan yang sama di hadapan hukum. Penjelasan Pasal 47 ayat (2) huruf e bagian c UU LLAJ, berbunyi: yang dimaksud dengan "kendaraan khusus" adalah kendaraan bermotor yang dirancang khusus yang memiliki fungsi dan rancang bangun tertentu, antara lain: c. alat berat antara lain: bulldozer, traktor, mesin gilas (stoomwaltz), forklift, loader, exvacator, dan crane.

Pemohon menganggap hak-hak konstitusionalnya dirugikan akibat keberadaan pasal a quo yang menempatkan alat berat sebagai kendaraan bermotor, padahal alat berat apabila dilihat dari fungsinya adalah alat produksi. Hal itu berbeda dengan kendaraan bermotor yang berfungsi sebagai moda transportasi baik barang maupun orang. Dengan kata lain, secara fungsional, alat berat tidak akan pernah berubah fungsi menjadi moda transportasi barang maupun orang. Dengan memperlakukan secara sama antara alat berat dengan kendaraan bermotor maka mengakibatkan:

a. Alat berat diharuskan mengikuti uji tipe dan uji berkala seperti halnya kendaraan bermotor. Persyaratan uji tipe dan uji berkala sebagaimana diatur dalam ketentuan di atas tidak mungkin dan tidak pernah dapat dipenuhi oleh alat berat karena karakteristik alat berat tidak pernah sama dengan kendaraan bermotor. Alat berat yang dimiliki oleh para Pemohon tidak memiliki ban karet seperti halnya kendaraan bermotor pada umumnya karena terbuat dari roda besi, sehingga tidak mungkin memenuhi syarat kedalaman alur ban, bahkan terdapat alat berat yang sama sekali tidak bergerak seperti halnya crane dan batching plant; b. Alat berat diharuskan memiliki perlengkapan kendaraan bermotor sebagaimana dimaksud dalam Pasal 57 ayat (3) UU LLAJ, padahal alat berat yang dimiliki para Pemohon tidak memiliki alat pendongkrak dan pembuka roda karena alat berat tidak memiliki ban;

c. Alat berat ternyata harus pula diregistrasikan dan diidentifikasi seperti halnya kendaraan bermotor sebagaimana diatur dalam Pasal 64 UU LLAJ yang pada pokoknya kendaraan bermotor diharuskan diregistrasi guna mendapatkan sertifikat uji tipe, padahal alat berat tidak dapat dilakukan uji tipe;

d. Alat berat ternyata harus dioperasikan hanya oleh orang yang memiliki SIM (surat izin mengemudi) seperti halnya berlaku bagi pengemudi kendaraan bermotor, sebagaimana diatur dalam Pasal 77 UU LLAJ dan khususnya ketentuan Pasal 80 ayat (2) UU LLAJ yang mensyaratkan SIM B II bagi operator alat berat. Ketentuan tersebut tentu tidak dapat dipenuhi oleh para Pemohon karena untuk mengoperasikan alat berat dibutuhkan keahlian tertentu yang tidak ada relevansinya dengan kemampuan seseorang yang sudah memiliki SIM B II. SIM sebagaimana diatur dalam Pasal 86 ayat (1) UU LLAJ sebagai bukti kompetensi mengemudi pada umumnya, artinya bukan untuk membuktikan atau menunjukkan kemampuan mengemudi pada umumnya, artinya bukan untuk menunjukkan kemampuan atau kompetensi mengoperasikan alat berat;

e. Dengan adanya pengelompokan alat berat sebagai kendaraan bermotor, para Pemohon berpotensi dikenakan sanksi pidana sebagaimana yang diatur dalam Pasal 277 UU LLAJ. 
Lebih lanjut, Pemohon menjelaskan dalam permohonannya bahwa penjelasan Pasal 47 ayat (2) huruf e bagian c UU LLAJ menimbulkan ketidakjelasan dan ketidakpastian hukum karena telah menempatkan alat berat sebagai kendaraan bermotor, padahal alat berat merupakan alat produksi yang memiliki jenis yang beranekaragam yang tidak mungkin dipersamakan dengan kendaraan bermotor sebagai moda transportasi, karena hal ini telah melanggar asas pembentukan peraturan perundang-undangan karena memasukkan norma baru ke dalam penjelasan yang secara kualitatif mengubah esensi batang tubuh.

Menanggapi permohonan Pemohon tersebut, Mahkamah berpendapat bahwa terdapat perbedaan antara kendaraan bermotor moda transportasi dengan alat berat. Alat berat didesain untuk melakukan kegiatan produksi yang terbatas dalam melakukan perjalanan/ perpindahan tempat oleh dirinya sendiri. Lebih lanjut, sebagaimana terdapat dalam putusan yaitu:

[3.16] Menimbang bahwa selain itu, Mahkamah juga menggarisbawahi dalam kaitannya dengan pengoperasian di jalan raya, alat berat juga memiliki perbedaan signifikan dengan kendaraan bermotor moda transportasi. Pada umumnya alat berat tidak didesain untuk melakukan perjalanan/perpindahan tempat oleh dirinya sendiri. Alat berat yang mampu melakukan perpindahan mandiri (berpindah tempat oleh kemampuan geraknya sendiri) pun memiliki batas kecepatan dan jarak tempuh yang sangat terbatas. Tentu hal ini menambah derajat perbedaan antara alat berat dengan kendaraan bermotor moda transportasi yang memang penggeraknya didesain demi mobilitas tinggi, yaitu berpindah dengan cepat dan jarak tempuh jauh;

Dengan demikian, pengaturan alat berat sebagai kendaraan bermotor seharusnya dikecualikan dari UU LLAJ, atau setidaknya terhadap alat berat tidak dikenai persyaratan yang sama dengan persyaratan bagi kendaraan bermotorpadaumumnyayang beroperasidijalan raya, yaitu sepeda motor dan mobil. Mewajibkan alat berat untuk memenuhi persyaratan teknis yang sama dengan persyaratan bagi kendaraan bermotor pada umumnya, padahal keduanya memiliki karakteristik yang sangat berbeda, adalah hal yang bertentangan dengan Pasal 28D ayat (1) dan Pasal 1 ayat (3) UUD 1945.

\section{Implikasi Putusan MK Nomor 3/ PUU-XIII/2015 Dalam Pembangunan Ekonomi Nasional di Bidang Alat Berat}

Dengan dikabulkannya untuk seluruh permohonan pengujian Undang-Undang No. 21 Tahun 2009 UU LLAJ terkait aturan pengelompokkan alat berat ke dalam kendaraan bermotor, mengandung makna bahwa pengaturan alat berat sebagai kendaraan bermotor seharusnya dikecualikan dari UU LLAJ atau setidaknya terhadap alat berat tidak dikenai persyaratan yang sama dengan persyaratan bagi kendaraan bermotor pada umumnya yang beroperasi di jalan raya, yakni mengikuti uji tipe dan uji berkala.

Melalui putusan Nomor 3/PUU-XIII/2015 aturan persyaratan bagi kendaraan bermotor seperti uji kir/tipe, uji berkala, dan termasuk pengenaan pajak kendaraan bermotor (PKB) tidak berlaku bagi kendaraan alat berat. Dengan demikian, bagi perusahaan kontraktor atau konstruksi yang kerap menggunakan kendaraan alat-alat berat dapat menjalankan usahanya tanpa dibebani persyaratan dimaksud. Karena uji tipe dan berkala tidak akan pernah dapat terpenuhi karena alat berat memiliki bahan karakteristik yang berbeda dengan kendaraan bermotor pada umumnya. 
Selain memberikan kelonggaran bagi para pengusaha alat berat, putusan a quo juga diharapkan dapat menarik investasi dari luar sehingga mampu menyerap tenaga kerja dan memberikan kontribusi bagi perekonomian daerah dan nasional.

\section{Prinsip Kepastian Hukum dalam Putusan MK Sebagai Upaya Mendorong Pembangunan Ekonomi Nasional}

Bahwa pada lingkungan negara-negara Eropa Barat Kontinental dan negara-negara konstitusional non-komunis lainnya, pengaturan tentang dasar-dasar kebijakan di bidang perekonomian dalam konstitusi memang tidak dianggap penting atau setidaknya tidak dirasakan keperluannya. Sebab utamanya ialah karena pengaruh tradisi Amerika Serikat yang mengembangkan pengertian konstitusi dalam arti politik semata, perekonomian merupakan urusan pasar yang sudah berjalan dengan sendiri tanpa diperlukan campur tangan pemerintah, sehingga dinilai bukanlah subjek yang harus diatur dalam konstitusi negara yang semula dinamakan articles of confideration. Namun karena berkembangnya kebutuhan, pemikiranpemikiran tentang ekonomi konstitusi juga terus berkembang dalam praktik, tidak saja di lingkungan negara-negara sosialis dan komunis, tetapi juga di lingkungan negara- negara barat non-komunis. Malahan sejak komunisme mengalami kebangkrutan, konstitusi-konstitusi negara-negara eks-komunis yang berubah menjadi demokrasi juga cenderung mengikuti pola perumusan konstitusi politik menurut tradisi Amerika Serikat. Akan tetapi, di Amerika Serikat sendiri mulai muncul pandangan baru yang mencerminkan kebutuhan untuk menjadikan konstitusi sebagai sumber rujukan dalam perumusan-perumusan kebijakan perekonomian. ${ }^{17}$

Misalnya, dalam pelbagai putusan Mahkamah Agung Amerika Serikat mulai muncul upaya untuk menafsirkan pasal-pasal konstitusi dari segi perekonomian atau economic interpretation of the constitution. Bahkan para ekonom juga semakin banyak mengembangkan pandangan yang kemudian dikenal sebagai cabang ilmu ekonomi politik (political economy) yang tersendiri seperti Wicksell, James $M$. Buchanan dan lain. ${ }^{18}$

Tujuan negara Indonesia adalah melindungi segenap Bangsa Indonesia dan seluruh tumpah darah Indonesia dan untuk memajukan kesejahteraan umum, mencerdaskan kehidupan bangsa dan ikut melaksanakan ketertiban dunia yang berdasarkan kemerdekaan, perdamaian abadi dan keadilan sosial. Untuk mewujudkan salah satu tujuan tersebut, dalam Pasal 33 UUD NRI 1945 dan merupakan prinsip yang mendasari pembentukan seluruh peraturan perundangundangan di bidang perekonomian. Konstitusi mengamanatkan agar pembangunan ekonomi nasional harus berdasarkan prinsip demokrasi yang mampu mewujudkan kedaulatan ekonomi Indonesia.

Fungsi kaidah hukum pada hakikatnya adalah untuk melindungi kepentingan manusia. ${ }^{19}$ Kaidah hukum bertugas mengusahakan

17 Jimly Asshiddiqie, Op. Cit., hlm. 64-65.

18 James McGill Buchanan, The Constitution of Economic Policy, Pidato Penerimaan Hadiah Nobel Ilmu Ekonomi di Stockholm, Swedia, 8 Desember 1986.

19 Sudikno Mertokusumo, Penemuan Hukum Sebuah Pengantar, (Yogyakarta: Liberty, 1996), hlm. 4. 
keseimbangan tatanan di dalam masyarakat dan kepastian hukum agar tujuannya tercapai, yaitu ketertiban masyarakat. Agar kepentingan manusia terlindungi, maka hukum harus dilaksanakan. Pelaksanaan hukum dapat berlangsung secara normal, damai, tetapi dapat terjadi juga karena pelanggaran hukum. Dalam hal inti hukum telah dilanggar itu harus ditegakkan. Melalui penegakan hukum inilah, hukum menjadi kenyataan. ${ }^{20}$ Penegakan hukum merupakan tiang utama yang memperkokoh fundamen yang menunjang kesejahteraan hidup masyarakat, dalam berbagai aspek kehidupan, menurut Soerjono Soekanto, ini dari proses penegakan hukum yang baik adalah penerapan yang serasi dari nilai-nilai dan kaidah-kaidah, yang kemudian terwujud dalam perilaku. Pola perilaku tersebut tidak terbatas pada warga masyarakat saja, akan tetapi mencakup juga golongan pattern setting group yang dapat diartikan sebagai golongan penegak hukum dalam arti sempit.

Dalam menegakkan hukum ada tiga unsur yang harus diperhatikan, yaitu: kepastian hukum (rechtssicherheit), kemanfaatan (zweckmassigkeit), dan keadilan (gerechtigkeit). Ketiga unsur tersebut oleh Gustav Radbruch dikatakan seabgai penopang cita hukum (idee des rechts). Cita hukum ini akan membimbing manusia dalam kehidupannya berhukum. ${ }^{21}$

Hukum dibentuk untuk mengatur kehidupan. Hukum tidak dapat berkembang tanpa dukungan ekonomi yang tumbuh. Tetapi perekonomian tidak akan tumbuh dan berkembang jika hukum tidak mampu menjamin keadilan yang pasti dan kepastian yang adil. Dengan demikian hukum juga dapat difungsikan sebagai sarana penggerak dan pengarah guna mencapai tujuan-tujuan suatu masyarakat di bidang perekonomian. ${ }^{22}$

\section{Hambatan Implementasi Putusan MK dalam Mewujudkan Pembangunan Ekonomi Nasional}

Penegakan hukum bukanlah penghambat pembangunan ekonomi, tetapi justru menjadi motor penggerak yang akan mengarahkan proses pembangunan ekonomi yang adil dan beradab. Penegakan hukum akan memastikan terwujudnya keadilan ekonomi, persaingan sehat dan pemerataan pembangunan di segala bidang.

Pemerintah sebagai addresat putusan selayaknya segera menindaklanjuti putusan MK. Putusan MK yang membatalkan ketentuan norma atau pasal, pada dasarnya melahirkan norma hukum yang setara dengan undang-undang, sehingga norma lain yang bertentangan dengan putusan dimaksud harus batal demi hukum. Tindakan pemerintah yang bertentangan dengan putusan MK, misal sikap Pemerintah yang mempertahankan alat berat sebagai bagian dari kendaraan bermotor dan tetap menarik pajak kendaraan bermotor (PKB) terhadap alat berat merupakan tindakan inkonstitusional karena telah menimbulkan ketidakpastian hukum dan ketidakadilan.

Tidak dipungkiri bahwa implementasi putusan MK tidak mudah. Harus diakui MK tidak memiliki aparat dan kelengkapan apapun untuk menjamin penegakan keputusannya. Implementasi putusan bergantung pada cabang kekuasaan lain atau organ-organ lain, apakah

$20 \quad$ Ibid., hlm. 11.

21 Satjipto Rahardjo, dkk, Refleksi dan Rekonstruksi Ilmu Hukum Indonesia, (Yogyakarta, Thafa Media, 2012), hlm. 284-285.

22 Jimly Asshiddiqie, Konstitusi Ekonomi, (Jakarta: PT Kompas Media Nusantara, 2010), hlm. 16. 
putusan-putusannya diterima dan apakah addressat putusan MK siap untuk mematuhinya.

Dalam perspektif negara hukum yang demokratis, diimplementasikannya putusan MK merupakan kewajiban hukum. Apalagi jika berkaitan dengan pemenuhan hak-hak konstitusional warga negara yang dijamin dan dilindungi oleh UUD NRI 1945 sebagai hukum tertinggi negara Indonesia. Jika putusan MK diabaikan dan tidak dilaksanakan, putusan tersebut akan menjadi mengambang (floating execution) yang menimbulkan ketidakpastian hukum. Kepastian hukum merupakan salah satu syarat yang harus dipenuhi dalam penegakan hukum. Esensi kepastian hukum sesungguhnya adalah perlindungan dari tindakan sewenangwenang, tidak saja dari negara melainkan juga oleh sekelompok pihak lain di luar negara. Dalam memahami nilai kepastian hukum harus diperhatikan adalah bahwa nilai itu mempunyai relasi yang erat dengan instrumen hukum positif dan peranan negara dalam mengaktualisasikannya dalam hukum positif.

\section{Penutup}

MK sebagai anak kandung reformasi yang memiliki fungsi sebagai the guardian of constitution dalam putusan MK Nomor 138/ PUU-XIII/2015 dan putusan MK Nomor 3/ PUU-XIII/2015 memberikan kesempatan bagi petani kecil perorangan dan pengusaha alat berat dalam menjalankan usahanya. Dengan diperbolehkannya para petani kecil perorangan dalam melakukan pemuliaan tanaman dan dihapuskannya ketentuan alat berat yang tidak lagi digolongkan sebagai kendaraan bermotor bagi pelaku usaha di bidang alat berat, diharapkan dapat mendukung pembangunan ekonomi nasional dari sektor industri kecil di bidang pemuliaan tanaman dan alat berat.
Namun, tidak dipungkiri bahwa kepatuhan addresat putusan MK yang tidak melaksanakan putusan MK menjadi hambatan dalam implementasi putusan a quo. Oleh karena itu, sebagai negara hukum konstitusional, menjadi kewajiban bagi seluruh organ negara untuk melaksanakan putusan MK secara sukarela. Dengan diimplementasikannya putusan MK, diharapkan dapat tercipta kepastian hukum yang mampu menciptakan kondisi yang membangun ekonomi nasional. Dengan demikian akan menjadi sinergi yang baik apabila putusan a quo segera diimplementasikan oleh semua addresat putusan, sehingga para petani dapat melaksanakan pemuliaan tanaman dengan bebas dan pelaku jasa konstruksi dapat menggunakan alat berat tanpa ada rasa takut terhadap kewajiban uji berkala.

\section{Daftar Pustaka}

\section{Buku}

Asshiddiqie, Jimly Asshiddiqie, Konstitusi Ekonomi, (Jakarta: PT Kompas Media Nusantara, 2010). Asshiddiqie, Jimly Asshiddiqie, Gagasan Konstitusi Sosial, (Jakarta: LP3ES, 2015).

Asshiddiqie, Jimly Asshiddiqie, Gagasan Kedaulatan Rakyat dalam Konstitusi dan Pelaksanannya di Indonesia, Disertasi Doktor dalam Ilmu Hukum Fakultas Hukum Universitas Indonesia, Jakarta 1991. Disertasi ini diterbitkan menjadi bku oleh Ichtiar Baru-Van Hoeve, Jakarta, 1994. Baca juga Jimly Asshiddiqie, Konstitusi Ekonomi (Jakarta: Penerbit Kompas, 2010).

Buchanan, James McGill Buchanan, The Constitution of Economic Policy, Pidato Penerimaan Hadiah Nobel IImu Ekonomi di Stockholm, Swedia, 8 Desember 1986.

Imaniyati, Neni Sri Imaniyati, Hukum Ekonomi dan Ekonomi Islam, (Bandung: Mandar Maju,2002). Imaniyati, Neni Sri Imaniyati, Hukum Bisnis Telaah Tentang Pelaku dan Kegiatan Ekonomi, (Yogyakarta: Graha IImu, 2009).

Mertokusumo, Sudikno Mertokusumo, Penemuan Hukum Sebuah Pengantar, (Yogyakarta: Liberty, 1996). 
Palguna, I Dewa Gede Palguna, Mahkamah Konstitusi, Judicial Review dan Welfare State: Kumpulan Pemikiran I dewa Gede Palguna, (Jakarta: Sekretariat Jenderal dan Kepaniteraan Mahkamah Konstitusi Republik Indonesia,2008).

Panggabean, R.M. Panggabean, Budaya Hukum Hakim Dibawah Pemerintahan Demokrasi dan Otoriter (Studi Tentang Putusan-Putusan Mahkamah Agung RI 1950-1965), (Jakarta: Pusat Studi Hukum dan Ekonomi Fakultas Hukum Universitas Indonesia, 2008).

Rahardjo, Satjipto Rahardjo, dkk, Refleksi dan Rekonstruksi Ilmu Hukum Indonesia, (Yogyakarta, Thafa Media, 2012).

Soemitro, Ronny Hanitidjo Soemitro, Studi Hukum Dalam Masyarakat, (Bandung: Alumni, 1982).

Suhardi, Gunarto Suhardi, Peranan Hukum Dalam Pembangunan Ekonomi, (Yogyakarta: Universitas Atmajaya, 2002).
Sulistyo, Adi \& Muhammad Rustamaji, Hukum Ekonomi Sebagai Panglima, (Sidoarjo: Masmedia Buana Pustaka, 2009).

Muhammad, Abdulkadir Muhammad, Hukum dan Penelitian Hukum. (Bandung: Citra Aditya Bakti, 2004).

W, Fredmann, The State and The Rule of Law in Mix Economy, London: Steven \& Son 1971, dan Geelhoed A, et. Al., Delntervierende Staat (Aazet een Instrumentenleer) Staauitgeveriij S'Gravenhage 1983).

\section{Putusan}

Putusan Mahkamah Konstitusi Nomor 3/PUUXIII/2015

Putusan Mahkamah Konstitusi Nomor 138/PUUXIII/2015 